\title{
UNJUK KERJA RICE TRANSPLANTER SISTEM JAJAR LEGOWO TIPE CROWN INDO JARWO DI KABUPATEN PINRANG SULAWESI SELATAN
}

\section{PERFORMANCE OF INDO JARWO RICE TRANSPLANTER CROWN TYPE ON JAJAR LEGOWO SYSTEM IN PINRANG REGENCY SOUTH SULAWESI}

\author{
Iqbal $^{1 凶}$, Yoesrifar Jafar $^{1}$, Tahir Sapsal ${ }^{1}$ \\ ${ }^{1}$ Program Studi Teknik Pertanian Universitas Hasanuddin \\ ${ }^{\square}$ Komunikasi Penulis, email: iqbaliqma@yahoo.com \\ DOI:http://dx.doi.org/10.23960/jtep-lv10i1.113-118 \\ Naskah ini diterima pada 1 Maret 2021; revisi pada 15 Maret 2021; \\ disetujui untuk dipublikasikan pada 17 Maret 2021
}

\begin{abstract}
Rice transplanters have been used in Pinrang district since 2017. The machines are initially grant from the Government through the Ministry of Agriculture. The type of rice transplanters that is mostly found within farmer groups are the Crown Indo Jarwo type. This study aims to identify and determine the theoretical and field capacity of rice transplanter, as well as field efficiency of the machine. The method used in this research was field experimental and descriptive analysis. The research was conducted at three different speeds on 3 plots of rice fields with each size of $10 \times 10$ meters. The results showed that the rate of $1.52 \mathrm{~km} /$ hour was a good speed to use in paddy fields with a working capacity of $8.5 \mathrm{~h} / \mathrm{ha}$. The results obtained from the calculation of the theoretical field capacity were $0.14 \mathrm{ha} / \mathrm{h}$ or $7.14 \mathrm{~h} / \mathrm{ha}$. The effective field capacity was $0.12 \mathrm{ha} / \mathrm{h}$ or $8.33 \mathrm{~h} / \mathrm{ha}$ with an efficiency of $86 \%$.
\end{abstract}

Keywords: field efficiency, rice, rice transplanter, work capacity

\begin{abstract}
ABSTRAK
Alat dan mesin (Alsin) tanam padi telah digunakan di kabupaten Pinrang sejak tahun 2017. Alsin tersebut merupakan bantuan dari Pemerintah melalui Kementerian Pertanian. Tipe alsin tanam padi yang banyak terdapat pada kelompok tani adalah tipe Crown Indo Jarwo. Penelitian ini bertujuan untuk mengidentifikasi dan mengetahui kapasitas kerja lapang dan teoritis alsin tanam, serta efisiensi lapang alsin tersebut. Metode yang digunakan dalam penelitian ini adalah eksperimental lapangan dan analisis deskriptif. Penelitian ini dilakukan dengan tiga kecepatan yang berbeda pada 3 petakan sawah dengan ukuran $10 \times 10$ meter. Hasil penelitian menunjukkan bahwa kecepatan 1,52 km/jam adalah kecepatan yang baik digunakan di lahan sawah dengan kapasitas kerja 8,5 $\mathrm{jam} / \mathrm{ha}$. Hasil perhitungan kapasitas lapang teoritis yang diperoleh adalah 0,14 ha/jam atau 7,14 jam/ha. Untuk kapasitas lapang efektif diperoleh 0,12 ha/jam atau 8,33 jam/ha dengan efisiensi sebesar 86\%.
\end{abstract}

Kata Kunci: efisiensi lapang, kapasitas kerja, padi, rice trans planter

\section{PENDAHULUAN}

Indonesia perlu melakukan pengembangan sektor pertanian. Hal ini bertujuan untuk meningkatkan produk pertanian, khususnya produk tanaman pangan. Proses penanaman padi yang dilakukan petani di Indonesia, secara umum masih tradisional dengan menggunakan metode konvensional, yaitu dengan sistem tapin atau tanam pindah. Bibit padi yang telah tumbuh di persemaian dipindahkan dan ditanam pada hamparan sawah sambil berjalan mundur atau tandur (tanam mundur). Metode penanaman ini membutuhkan tenaga kerja yang banyak sehingga usaha pertanian menjadi tidak efisien. Padahal untuk memperoleh keuntungan dan hasil yang baik dalam usaha tani, efisiensi dan efektifitas menjadi aspek yang perlu diperhatikan pada budidaya tanaman padi.

Untuk meningkatkan produksi padi pada per satuan luas sawah perlu dilakukan usaha intensif 
dengan penggunaan varietas yang dapat memberikan hasil yang tinggi. Meotode atau budidaya tanaman yang tepat, disertai penerapan teknologi alat dan mesin (alsin) pertanian, tentunya akan dapat meningkatkan produksi dan efisiensi kerja pada usaha pertanian (Iriana, 2009). Selain itu, penanganan pascapanen padi yang baik dan tepat, juga merupakan satu upaya yang sangat bijak dan strategis dalam rangka mendorong peningkatan produksi padi (Iqbal et al, 2018).

Produksi padi Indonesia tahun 2013 sekitar 50,4 juta ton GKG (Gabah Kering Giling), ini meningkat 32,82 ribu ton GKG $(0,66 \%)$ dari produksi padi pada tahun 2012 . Hal ini disebabkan oleh pertambahan luas panen sekitar 17124 ribu hektar $(0,17 \%)$ dan peningkatan produktivitas lahan sekitar 0,25 kuintal per hektar $(0,48 \%)$. Namun menurut Iqbal et al (2019), kebutuhan beras yang menjadi makanan pokok oleh hampir semua orang Indonesia (96,87\% dari total populasi) dan menyumbang lebih dari 90\% dari kebutuhan kalori. Populasi penduduk sekitar 260 juta jiwa dan pertumbuhan penduduk tahunan sebesar 1,49\%, maka kebutuhan pangan khususnya beras, secara nasional akan mencapai 40 juta ton.

Rice transplanter dapat memberikan solusi untuk mengatasi permasalahan yang ada di tingkat petani. Rice transplanter atau alat dan mesin (alsin) merupakan teknologi pertanian yang modern. Alsin ini berfungsi untuk membantu dan memudahkan proses penanaman bibit padi. Dengan adanya alat dan mesin tanam ini, tentunya dapat mempercepat waktu penanaman bibit padi sehingga laju peningkatan produksi padi dapat dicapai. Ini penting untuk mengimbangi laju pertambahan jumlah penduduk yang terus meningkat, sehingga kebutuhan pangan penduduk dapat terpenuhi. Di Indonesia, rice transplanter telah digunakan sejak tahun 1986 yang berasal dari Jepang. Rice transplanter tersebut digunakan oleh Balai Benih Padi di beberapa daerah. Pinrang merupakan salah satu daerah yang telah menggunakan rice transplanter saat penanaman bibit padi di sawah.

Rice transplanter merupakan alsin tanam yang digunakan untuk penanaman bibit padi yang disemaikan terlebih dahulu pada tempat tertentu yang disebut dapog (tray) dengan lama waktu penyemaian sekitar 15-20 hari. Rice transplanter juga dirancang untuk beroperasi di lahan sawah dengan kedalaman lumpur yang dalam, karena dilengkapi dengan alat pengapung.

Penyemaian benih padi dengan menggunakan dapog telah banyak dilakukan oleh petani di Jepang. Penyemaian tersebut dilakukan oleh pusat koperasi pertanian, sehingga para petani menjadi tidak repot untuk menyiapkan bibit padi yang akan mereka tanam. Penyemaian benih padi dengan metode ini dapat meningkatkan keseragaman bibit dan diproduksi dalam jumlah yang besar. Dengan demikian alat dan mesin (alsin) tanam dapat bekerja lebih efektif, efisien, akurat, stabil dan cepat (Hapsari, 2018).

Rancangan alsin tanam padi (transplanter) merupakan alsin pertanian yang digunakan untuk menanam bibit padi hasil penyemaian yang disemai terlebih dahulu. Cara kerja alat ini adalah dengan memanfaatkan putaran roda sebagai sumber pergerakan. Putaran roda akan memutar sistem poros engkol. Poros engkol membawa batang penanam bergerak sesuai lintasan tertentu. Lintasan pergerakan batang penanam ini dimanfaatkan untuk menanam bibit ke tanah (Oktaviana, 2013).

Indo Jarwo Transplanter merupakan alsin pertanian untuk menanam bibit padi dengan 4 baris. Alsin tanam Indo Jarwo Transplanter memiliki total panjang, $.48 \mathrm{~m}$, tinggi $86 \mathrm{~cm}$ dan lebar $1,70 \mathrm{~m}$. Sumber tenaga penggerak yang digunakan pada alsin ini yaitu motor bakar bensin 4 langkah (tak), memiliki daya sebesar $3.5 \mathrm{~kW}$ (4.6 HP) serta putaran enjin $3600 \mathrm{rpm}$. Untuk sekali gerak perputaran roda, terdapat 4 jalur bibit tanaman yang tertancapkan di lahan sawah. Pola jajar legowo pada alsin ini adalah 2:1. Pola ini memeliki jarak alur tanam 20-40$20 \mathrm{~cm}$. Alsin ini mudah dioperasikan oleh para petani. Prinsip kerja dari alsin ini adalah bibit padi diambil dan ditancapkan ke dalam lumpur oleh garpu/jari penanam (picker) (Umar et.al, 2017).

Kelebihan dari Indo Jarwo transplanter adalah dirancang untuk mendukung pola tanam jarwo 
2:1 dengan 4 baris. Adapun jarak barisnya 20 $\mathrm{cm}$, dan jarak legowonya $40 \mathrm{~cm}$. Kapasitas kerja alsin tanam ini mencapai 6 jam/ha. Jarak tanam dalam baris juga dapat diatur dengan jarak 10$18 \mathrm{~cm}$. Hasil penanaman dari alsin ini akan lebih presisi. Selain itu, tingkat kedalaman tanam juga dapat diatur pada kedalaman 3-6 cm dengan jumlah bibit padi yang tertanam dalam satu lubang berkisar antara 2-4 bibit tanaman. Dengan demikian jarak maupun kedalaman tanam akan seragam. Keseragaman ini akan dapat meningkatkan pertumbuhan sehingga hasil penanaman dapat lebih optimal (Umar et al, 2017).

Alsin tanam Indo Jarwo transplanter termasuk dalam alsin tanam padi yang berpenggerak sendiri (self-propulsion type) yang cara pengoperasiannya yaitu operator berada dibelakang mesin. Menurut Aini (2017), adapun bagian-bagian dari Indo Jarwo transplanter ditampilkan pada Gambar 1.

Kabupaten Pinrang adalah kabupaten yang penduduknya sebagian besar berprofesi sebagai petani. Di kabupaten Pinrang alat tanam bibit padi (rice transplanter) sudah sering digunakan, namun belum diketahui efisiensi dari penggunaan alat tersebut jika dibandingkan dengan proses penanaman bibit padi secara konvensional, belum diketahui berapa kecepatan efektif yang baik digunakan dalam proses penanaman bibit padi menggunakan alat ini.

Uraian di atas yang melatarbelakangi penelitian ini perlu dilakukan. Penelitian ini akan memberikan informasi tentang efisiensi kerja alat tanam bibit padi (rice transplanter) serta kecepatan yang efektif untuk penggunaan rice transplanter di Kabupaten Pinrang. Penelitian ini bertujuan untuk : a) Menghitung dan mengetahui kapasitas kerja alsin tanaman padi Indo Jarwo transplanter. b) Menghitung efisiensi kerja alsin tanam bibit padi Indo Jarwo transplanter. c) Mengetahui kecepatan yang efektif penggunaan alsin tanam bibit padi Indo Jarwo transplanter di Kabupaten Pinrang.

\section{BAHAN DAN METODE}

Penelitian ini menggunakan bahan-bahan sebagai berikut: benih padi varietas Inpari 30 , bahan bakar minyak jenis premium, air pendingin, minyak pelumas motor penggerak, minyak pelumas tranmisi. Adapun peralatan yang digunakan adalah alsin tanam bibit padi tipe Indo Jarwo Transplanter, meteran, patok, stopwatch, dapog berukuran $18.3 \mathrm{~cm}$ x $58 \mathrm{~cm}$, dan penggaris.

\subsection{Metode Penelitian}

Penelitian ini dilakukan di areal persawahan yang siap tanam. Lahan tersebut berlumpur sedalam $32 \mathrm{~cm}$ dengan air tergenang $\pm 1 \mathrm{~cm}$. Ukuran lahan yang digunakan berdimensi $30 \mathrm{~m}$ $\mathrm{x} 10 \mathrm{~m}$.

Lahan tersebut dibagi menjadi 3 bagian, dengan ukuran masing-masing lahan $10 \mathrm{~m} \times 10 \mathrm{~m}$. Perlakuan uji sepanjang $10 \mathrm{~m}$ dengan minimal 5 kali ulangan menggunakan kecepatan berbeda pada tiap petakan lahan sawah. Perlakuan

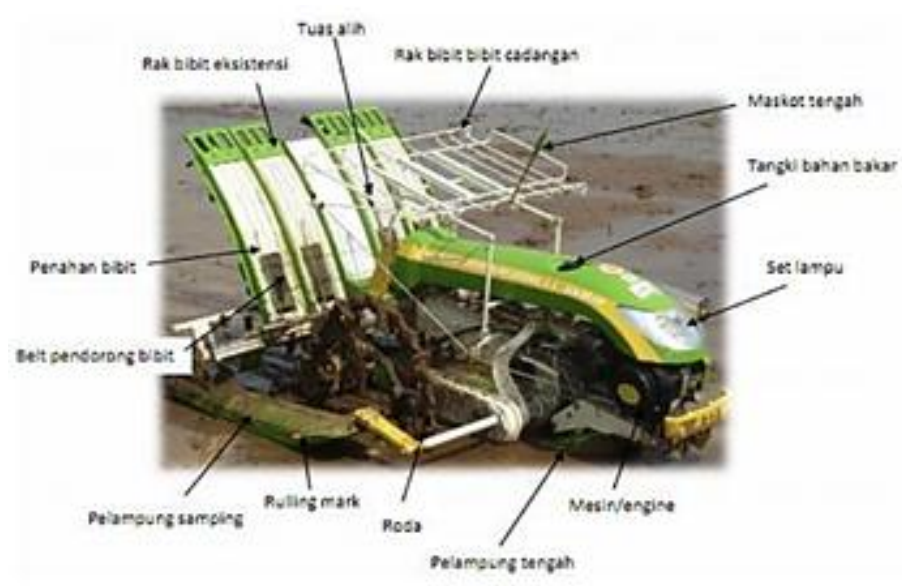

Gambar 1. Bagian-bagian Indo Jarwo Transplanter (Aini, 2017) 
kecepatan yang digunakan adalah $1,52 \mathrm{~km} / \mathrm{jam}$, kecepatan 1,76 km/jam, dan kecepatan 2,08 km/ jam.

\subsection{Parameter yang Diamati}

\section{a. Kapasitas Lapang Penanaman}

Kapasitas lapang suatu alsin terbagi 2, yakni Kapasitas Lapang Teoritis (KLT) dan Kapasitas Lapang Efektif (KLE). KLT merupakan perhitungan kapasitas lapang, diman efisiensi lapang sama dengan satu atau $100 \%$ berarti alsin tersebut bekerja sempurna tanpa waktu membelok atau berhenti. Dengan demikian, perhitungan KLT merupakan perhitungan kapasitas lapang dengan mengukur lebar alat dan kecepatan kerja (Srivastava, 1993). Kapasitas lapang teoritis (KLT) dihitung menggunakan Persamaan 1 (Hadiutomo, 2012):

$$
K L T=\frac{W t x V t}{10}
$$

dimana, KLT adalah kapasitas lapang teoritis (ha/jam), Wt adalah lebar kerja alsin tanam (m), dan Tt adalah Total waktu operasi (jam).

Kapasitas lapang efektif (KLE) adalah total waktu operasi alsin untuk menyelesaikan pekerjaan berbanding luasan tanah (Srivastava, 1993). Persamaan untuk menghitung kapasitas lapang efektif dapat dihitung dengan Persamaan 2 adalah (Hadiutomo, 2012):

$$
K L E=\frac{A}{T p}
$$

dimana, KLE adalah kapasitas lapang efektif (ha/ jam), A adalah luas lahan tertanami (ha), dan Tp adalah Total waktu operasi (jam).

\section{b. Efisiensi Lapang}

Efisiensi alsin sangat tergantung pada kapasitas lapang efektif dan kapasitas lapang teoritis penanaman. Efisiensi adalah perbandingan antara kapasitas lapang efektif (KLE) dengan kapasitas lapang teoritis (KLT) dan dinyatakan dalam persen (\%) (Yuswar, 2004). Untuk menghitung Efisiensi Lapang ( $E f$ ) digunakan Persamaan 3 (Hadiutomo, 2012):

$$
E f=\left(\frac{K L E}{K L T}\right) \times 100 \%
$$

\section{HASIL DAN PEMBAHASAN}

\subsection{Kapasitas Kerja}

Penelitian ini menggunakan alsin tanam Indo Jarwo transplanter. Alsin ini merupakan alsin penanam bibit padi yang telah disemai pada tempat tertentu yang disebut dapog atau tray. Keunggulan alsin tanam Indo Jarwo transplanter adalah dapat mendukung sistem tanam jajar legowo 2:1 dengan jumlah baris tanam sebanyak 4 baris.

Hasil pengukuran dan perhitungan yang diperoleh dari penelitian yang dilakukan menunjukkan bahwa lebar kerja teoritis alat tanam adalah $0,8 \mathrm{~m}$. Penelitian ini menggunakan tiga kecepatan berbeda yakni kecepatan 1.52 $\mathrm{km} / \mathrm{jam}, 1.76 \mathrm{~km} / \mathrm{jam}$, dan 2,08 km/jam. Hasil penelitian yang dilakukan di lahan sawah diperoleh pengerjaan total pada tiap petak lahan sawah dengan ukuran 0,01 ha pada kecepatan $1,52 \mathrm{~km} /$ jam selama 0,084 jam, pada kecepatan $1,76 \mathrm{~km} / \mathrm{jam} 0.075 \mathrm{jam}$ dan pada kecepatan 2,08 $\mathrm{km} / \mathrm{jam}$ selama 0,067 jam. Dari data tersebut dapat dilihat bahwa kecepatan kerja alat tanam padi (rice transplanter) berbanding lurus dengan waktu yang digunakan selama proses pengoperasian di lahan sawah dan dapat dilihat pula bahwa waktu kerja yang dibutuhkan dalam proses penanaman padi pada lahan seluas 0.01 ha adalah 0.067 hingga 0.084 jam atau memerlukan 6 hingga 8 jam untuk menyelesaikan proses penanaman pada lahan sawah seluas 1 ha. Hal ini sesuai dengan hasil penelitian Umar (2017) yang melakukan penelitian di lahan rawa pasang surut dengan menggunakan kecepatan $2.34 \mathrm{~km} / \mathrm{jam}$ dan mendapatkan nilai kapasitas kerja sebesar 6.15 jam/ha.

\subsection{Kapasitas Lapang Teoritis (KLT)}

Hasil penelitian yang telah dilakukan didapatkan hasil perhitungan Kapasitas Lapang Teoritis (KLT). Pada kecepatan 1,52 km/jam didapatkan KLT 0,14 ha/jam atau setara 7,31 jam/ha. Pada kecepatan 1,76 km/jam diperoleh KLT 0,16 ha/ jam atau setara 6,31 jam/ha. Dan untuk kecepatan 2,08 km/jam diperoleh KLT 0,19 ha/ jam atau setara 5,34 jam/ha. Dari data tersebut diperoleh bahwa untuk menyelesaikan proses penanaman bibit padi menggunakan alsin tanam Indo Jarwo Transplanter dibutuhkan waktu 5-7 jam/ha. Hasil perhitungan KLT menggunakan 
alsin tanam Indo Jarwo transplanter ini tidak sesuai dengan hasil percobaan atau penelitian yang dilakukan oleh Dai (2019) di Desa Tuyak Kecamatan Lolak yang menggunakan Rice transplanter dengan tipe yang sama. Hasil perhitungan dari penelitian Dai (2019) diperoleh KLT sebesar 0,235 ha/jam dengan kecepatan mesin 1,95 km/jam. Perbedaan ini disebabkan oleh kondisi lahan yang mereka gunakan lebih baik karena proses pelumpuran yang baik pula dan menggunakan waktu yamg lama, sehingga menghasilkan lahan sawah yang sempurna untuk ditanami menggunakan tice transplanter tipe Crown Indo Jarwo yakni dengan kedalaman lumpur $23 \mathrm{~cm}$ dan digenangi air setinggi $2 \mathrm{~cm}$.

\subsection{Kapasitas Lapang Efektif (KLE)}

Perhitungan KLE adalah perhitungan total waktu yang dibutuhkan alsin untuk menyelesaikan pekerjaan berbanding luasan lahan. Ini bertujuan untuk mengetahui berapa waktu yang dibutuhkan alsin tanam Indo Jarwo transplanter untuk melakukan proses penanaman pada luasan lahan sawah tertentu. Pada perhitungan Kapasitas Lapang Efektif dari penelitian ini didapatkan hasil dimana pada kecepatan 1,52 $\mathrm{km} / \mathrm{jam}$ adalah $0,12 \mathrm{ha} / \mathrm{jam}$ atau setara $8,5 \mathrm{jam} /$ ha, pada kecepatan $1,76 \mathrm{~km} / \mathrm{jam}$ diperoleh KLE $0,13 \mathrm{ha} / \mathrm{jam}$ atau setara 7,6 jam/ha, dan pada kecepatan 2,08 km/jam diperoleh KLE 0,15 ha/ jam atau setara 6,7 jam/ha. Dari data tersebut dapat dilihat bahwa waktu pengerjaan yang diperoleh dari nilai KLE adalah 6-8 jam untuk menyelesaikan penanaman di lahan seluas 1 ha.

Nilai KLE minimum pada (SNI 7607:2010) adalah sebesar 0,15 ha/jam. Hasil pengukuran di lapangan ternyata berbeda, dimana didapatkan nilai KLE minimum yang diperoleh adalah 0,12 ha/jam yakni pada kecepatan 1,52 km/jam. Ini sesuai dengan penelitian Oktaviana (2013) di Subang Jawa Barat, menggunakan transplanter tipe sama dengan sistem tanam tegel dengan kecepatan $1.87 \mathrm{~km} / \mathrm{jam}$, nilai KLE yang didapatkan adalah 0,13 ha/jam. Hal ini disebabkan oleh kondisi dan topografi lahan. Selain itu keterampilan operator juga sangat berpengaruh dalam mengoperasikan alat. Sebagaimana hasil penelitian Umar (2017) yang menunjukkan bahwa kapasitas kerja mesin tanam sangat dipengaruhi oleh luas petakan sawah yang ditanami, kondisi lahan, serta keterampilan operator dalam menjalankan alat.

\subsection{Efisiensi Lapang}

Berdasarkan perhitungan nilai KLT dan KLE yang diperoleh, maka didapatkan nilai efisiensi dari penelitian ini. Dimana nilai efisiensi dari kerja alat rice transplanter tipe Crown Indo Jarwo yang terbesar pada kecepatan 1,52 km/jam dengan persentasi sebesar $86 \%$ sedangkan nilai efisiensi terendah didapatkan dari kecepatan 2,08 km/ jam dengan persentasi sebesar 79\%.

Nilai efisiensi yang didapatkan pada penelitian ini sesuai dengan (SNI 7607:2010) dimana efisiensi lapang minimum rice transplanter adalah sebesar 70\%. Dari data yang diperoleh pada penelitian ini dapat dikatakan bahwa alat tanam padi (rice transplanter) ini layak digunakan pada lahan sawah di desa sikkuale karena efisiensi penanaman nya yang lebih dari $50 \%$. Efisiensi yang didapatkan tentunya sangat dipengaruhi oleh luasan lahan pengujian, dimana luas lahan berpengaruh pada hasil perhitungan dari KLT dan KLE. Ini sejalan dengan hasil penelian Yuswar (2004) yang memperlihatkan bahwa efisiensi alat penanaman pertanian tergantung pada nilai kapasitas lapang efektif dan kapasitas lapang teoritis.

\section{KESIMPULAN}

Kapasitas kerja alat yang meliputi nilai KLT dan KLE pada kecepatan adalah $(0,14 \mathrm{ha} / \mathrm{jam}$ dan $0,12 \mathrm{ha} / \mathrm{jam})$, pada kecepatan $\mathrm{km} / \mathrm{jam}, 1,76 \mathrm{~km} /$ jam adalah $(0,16 \mathrm{ha} / \mathrm{jam}$ dan $0,132 \mathrm{ha} / \mathrm{jam})$, dan pada kecepatan 2,08 km/jam adalah $(0,19 \mathrm{ha} /$ jam dan 0,15 ha/jam). Berdasarkan tiga kecepatan uji kerja, nilai efisiensi kerja alat mencapai $86 \%$. Kecepatan yang baik digunakan untuk proses penanaman bibit padi menggunakan rice transplanter tipe Crown Indo Jarwo di Kabupaten Pinrang adalah kecepatan $1,76 \mathrm{~km} / \mathrm{jam}$.

\section{DAFTAR PUSTAKA}

Aini, F.N. 2017. Mesin Penanam dan Alat Penanam Tradisional. [Skripsi]. Universitas Muhammadiyah Gresik. Gresik. 
Badan Standardisasi Nasional (BSN). 2010. SNI 7607;2010. Mesin Tanam Bibit Padi Tipe Dorong - Syarat Mutu dan Metode Uji. Jakarta.

Dai., Rantung, R.A., dan Pangkerego, F. 2019. Uji Teknis Crown Indo Jarwo Transplanter di Desa Tuyat Kecamatan Lolak. Universitas Sam Ratulangi. Manado.

Hadiutomo, K. 2012. Mekanisasi Pertanian. IPB Press. Bogor.

Hapsari, P. 2018. Adopsi Teknologi Rice Transplanter. [Skripsi]. Universitas Muhammadiyah Surakarta. Jawa Tengah.

Iqbal., Achmad, M., dan Sapsal, M.T. 2019. Organic Fertilizer Applicators Design For Supporting Rice Production. IOP Conf. Series: Earth and Environmental Science 235 (2019) 012038.

Iqbal, Suhardi Suhardi, Sri Ayu Nirisnawati. Uji Unjuk Kerja Alat dan Mesin Perontok Multiguna 2018. JRPB, 6(1): 12-16. D OI:https://doi.org/10.29303/ jrpb.v6i1.73.

Iriana., D.W. 2009. Lampu Merah Swasembada Beras. Agrina 25 November 2009:6. http:/ /www.agrina-online.com/detail-berita/ 2009/11/25/7/2139/lampu-merahswasembada-beras. (diakses pada 1 Maret 2021).

Octiasari. 2011. Hubungan Penugasan Lahan Sawah dengan Pendapatan Usahatani Padi. [Skripsi]. Institut Pertanian Bogor. Bogor

Oktaviana, R. 2013. Studi Unjuk Kerja Penanaman Bibit Padi Secara Mekanis di Desa Sukamandi, Subang, Jawa Barat. [Skripsi]. Institut Pertanian Bogor. Bogor.

Srivastava, A.K., Goering, C.E., dan Rohrbach, R.P. 1996. Engineering Principles of Agricultural Machines. American Society of Agricultural Engineering. Amerika.

Umar, S dan Pangaribuan,S. 2017. Evaluasi Penggunaan Mesin Tanam Bibit Padi (Rice Transplanter) Sistem Jajar Legowo di Lahan Pasang Surut. Jurnal Teknik Pertanian Lampung, 6 (2) : 105-114.

Yuswar, Y. 2004. Perubahan Beberapa Sifat Fisik Tanah dan Kapasitas Kerja Traktor Akibat Lintasan Bajak Singkal pada Berbagai Kadar Air Tanah. [Tesis]. Universitas Syiah Kuala Banda Aceh. Banda Aceh. 